\title{
USE OF AN OXIDATIVE DESTRUCTION AND QUADRUPOLE MASS SPECTROMETRIC (QMS) DETECTION FOR THE DETERMINATION OF THE ORGANIC ELEMENTAL COMPOSITION OF SUSPENDED MATTER IN SURFACE WATER
}

\author{
H. F. R. ReIJNDERS ${ }^{1}$, D. ONDERdelinden ${ }^{1}$, M. G. Visser ${ }^{2}$ and B. GRIepink ${ }^{2}$ \\ ${ }^{1}$ National Institute of Public Health, Anthonie van Leeuwenhoeklaan 7, 2560 BA Bilthoven and \\ ${ }^{2}$ Laboratory for Analytical Chemistry, Utrecht University, The Netherlands
}

(Received May 1980)

\begin{abstract}
A study was made of the applicability of a system consisting of a combustion followed by QMS-detection for the determination of the elemental composition of organic matter suspended in surface water. The solid material obtained from several types of water was collected by centrifugation. The results show possible applications e.g. in the field of water characterization. A complete elemental analysis including pretreatment takes about $30 \mathrm{~min}$.
\end{abstract}

\begin{abstract}
Zusammenfassung - Die Anwendung einer Kombination von Verbrennung und Detektion der Verbrennungsprodukte mittels QMS zur Ermittlung der Elementzusammensetzung von in Wasser suspendiertem organischen Material wurde studiert. Die Festkörper wurden mittels Centrifugation abgetrennt. Die Ergebnisse weisen mögliche Anwendungen auf, z.B. bei der Wasserkennzeichnung. Eine Elementaranalyse inkl. Vorbehandlung fördert etwa $30 \mathrm{Min}$.
\end{abstract}

The elemental composition of organic parts of the insoluble matter in surface water is of increasing interest in the study of water pollution and the elucidation of the various mechanisms involved in the metabolization of waste and natural organic material. The composition of the organic material is rather complex, because many industrial compounds and metabolites of fats, proteins and carbohydrates may occur. Therefore a complete structural analysis giving the type of compounds and their concentration is unpractical and nearly impossible.

Elemental analysis, however, may give useful information on the type of the compounds, e.g. fats or proteins, present. Recently Baumeister (1978) performed CHN-analyses on the suspended matter present in surface water. He found a rather uniform $\mathrm{C} / \mathrm{N}$-ratio in the particles from various samples. This may indicate a merely biogenic origin.

As micro-organisms and pollutants have a tendency to grow resp. to be adsorbed on solid particles, the amount of organic material on the solid particles and its composition may be useful to characterize the type of water. So in our first investigation we sampled completely different water sources (Table 1 ).

The temporal behaviour of the elemental composition might also provide a means to obtain a better knowledge and understanding of the chemical and biological processes in the water. The direct study of these mechanisms in surface water may be too complicated yet. For the study of these processes in controllable model systems, elemental analysis could be useful.
For both research objects the analysis should meet certain demands. The first demand is that various elements should be determined. Sulphur for example is an important constituent of certain proteins and their metabolites and should therefore be determined. Another demand is that the determinations can be carried out on a routine basis to be able to analyse a large amount of samples necessary for correlation and model studies. For a first investigation the demands with regard to the accuracy of the method are less rigid than in usual elemental analysis of organic com. pounds.

These considerations lead us to investigate the use of the destruction/QMS-combination recently published by van Leuven $(1970,1973)$.

\section{EXPERIMENTAL}

\section{Reagents}

For calibration of the apparatus $S$-benzyl-thiuromium hydrochloride and 4-chlorobenzoic acid are used. These reagents are abbreviated as PTU and CBA respectively.

\section{Apparatus}

A diagram of the apparatus is given in Fig. 1. The combustion tube (i.d. $24 \mathrm{~mm}$ ) is heated to a temperature of approx. $1000^{\circ} \mathrm{C}$ in a furnace (Heraeus ROK 30 and REK 19120). The tube is separated in two compartments I and II by means of a partition of quartz glass provided with an opening of $10 \mathrm{~mm}$ allowing passage of gasses.

The sample is weighed in a platinum boat with an electrical microbalance (Cahn 270). The boat is introduced on a quartz spoon(s) in compartment I. Organic material is 
Table 1. Origin of the samples, corresponding amount of suspended matter, inorganic fraction $(\mathrm{w} / \mathrm{w})$ and suspected source of organic material

\begin{tabular}{|c|c|c|c|c|}
\hline $\begin{array}{l}\text { Sample } \\
\text { number }\end{array}$ & Origin & $\begin{array}{c}\text { Suspected source } \\
\text { of the organic } \\
\text { material }\end{array}$ & $\begin{array}{l}\text { Suspended } \\
\text { matter } \\
\left(\mathrm{mg} \mathrm{l}^{-1}\right)\end{array}$ & $\begin{array}{l}\text { Inorganic } \\
\text { fraction }\end{array}$ \\
\hline 1 & Effluent of a wastewater treatment plant & Sewage water & 134.0 & 0.25 \\
\hline 2 & Efifuent of a wastewater treatment plant & Sewage water & 103.0 & 0.24 \\
\hline 3 & Lek (river) & Various & 38.0 & 0.80 \\
\hline 4 & Ditch & Various & 54.4 & 0.64 \\
\hline 5 & Vecht (river) & Various & 9.4 & 0.58 \\
\hline 6 & Amsterdam-Rijnkanaal (canal) & Various & 13.3 & 0.75 \\
\hline 7 & Merwedekanaal (canal) & Various & 20.0 & 0.78 \\
\hline 8 & Vaartse Rijn (canalised river) & Various & 8.5 & 0.69 \\
\hline 9 & Catharijnesingel Utrecht (canal) & Sewage water & 15.1 & 0.65 \\
\hline 10 & Kromme Rijn (canalised river) & Industrial wastes & 14.2 & 0.66 \\
\hline 11 & Nieuwe Gracht Utrecht (canal) & Various & 12.6 & 0.65 \\
\hline 12 & Biltse Grift (brook) & Sewage water & 14.7 & 0.55 \\
\hline
\end{tabular}

combusted in an axygen atmosphere. The oxygen, delivered via flow rator $R_{1}\left(80 \mathrm{ml} / \mathrm{min}^{-1}\right)$ not only supplies oxygen for combustion but also avoids entry of ambient air by flushing oxygen through the entrance (e). The combustion is catalysed by Pt-wool (w) which is squeezed in the opening in the partition. In compartment II the combustion is completed. The oxygen is supplied via flow rator $R_{2}(25 \mathrm{ml}$ $\left.\min ^{-1}\right)$ and flow rator $R_{3}\left(7 \mathrm{mi} / \mathrm{min}^{-1}\right)$. The oxygen stream through $R_{3}$ is humidified prior to passage in a gas washing bottle filled with water. This gas washing bottle is thermostated in a water bath (temp. approx. $25^{\circ} \mathrm{C}$ ). From compartment II the gasses enter the gassplitter (gs) via the first pressure reduction device $P_{1}$. The pressure reduction is variable and can be set manually by cock $c$. The pressure is maintained by a rotating vacuum pump. The gasses are introduced in the quadrupole mass spectrometer (QMS) via the second pressure reduction device $P_{2}$ consisting of a capillary (i.d. $0.5 \mathrm{~mm}$ ) and Pt-wire. The pressure reduction can be set by varying the length of $P$ t-wire in the capillary. The pressure in the QMS is maintained with a turbomolecular pump (Pteiffer TPU 200). The mass spectrometer is a Balzers QMG 311. The QMS has a thorium-iridium cathode for the electron-impact ionization. After accelerating. the ions pass the mass filter and are selected to mass to charge ratio.

Masses are scanned by varying the a.c.-voltage applied to the mass filter. A computer program (CAMAC-processor) controls the detection in such a way that the ion current at a sequence of twelve different mass units is measured repeatedly and recorded. The time needed for the measurement at every mass to charge ratio amounts to $70 \mathrm{~ms}$ which includes steptime, dead time, sampling time, converting time and computation time. During the complete combustion every mass fraction is measured 270 times. The ion current on combustion of a sample at one mass to charge ratio is presented in Fig. 2. The actual measurement takes about 210.s. The background current is measured during $105 \mathrm{~s}$ before and after the combustion $\left(t_{1}-t_{2}, t_{3}-t_{4}\right.$ resp. $)$.

The CAPRO-system sums the several collected ion current values per mass to obtain the area under the time curve. These values from the CAPRO-system are read out via a terminal on paper tape. The processing of data is carried out by a $21 \mathrm{MX}$ computer after reading the data from paper tape. The signal from the QMS-electronics may be monitored on an oscilloscope.

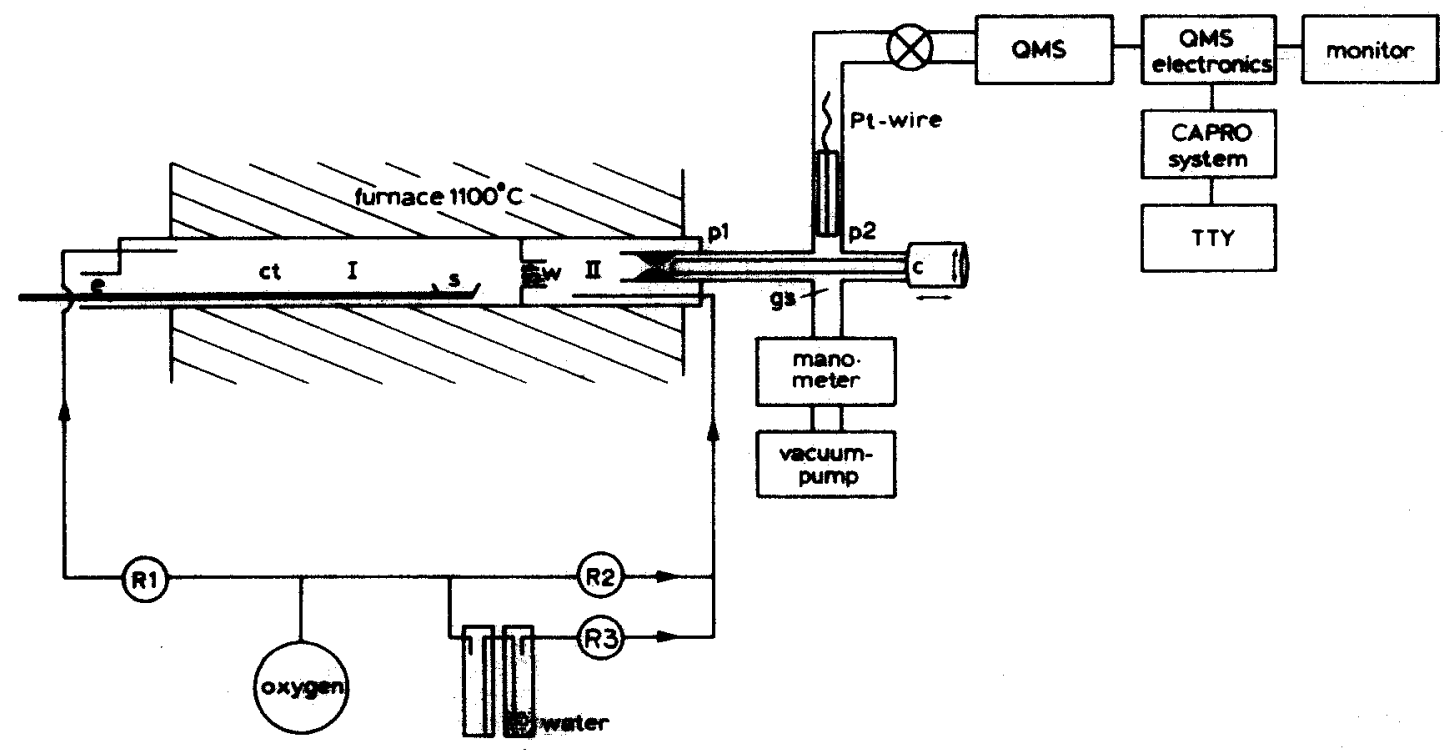

Fig. 1. Scheme of the analyser. 


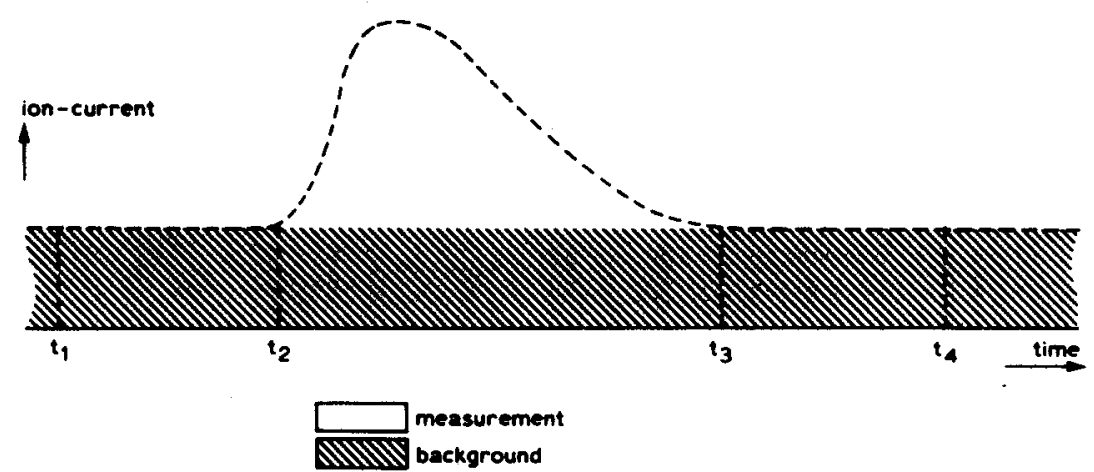

Fig. 2. Ion current (output multiplier) on combustion of a sample at one mass to charge ratio.

Sampling

Five litres of surface water were sampled with an aluminium device. Whirling of the silt on the bottom of the sampling site was carefully avoided. The sample was transported in a metal container. The sample storage time was always less than two days.

\section{Procedure}

The sample is divided in 11 . aliquots. These aliquots are centrifuged at $2400 \mathrm{rpm}$ during $5 \mathrm{~min}$. The liquid is decanted. The solid residues are gathered and centrifuged once more. The solid is dried in a dessicator above silicagel to constant weight. Subsamples containing about $1 \mathrm{mg}$ of organic material are taken. Subsamples are burned in the combustion tube. Ion currents (at mass to charge ratios of $18,44,14,64$ and 36 ) are measured for determination of $\mathrm{H}$, $\mathrm{C}, \mathrm{N}, \mathrm{S}$ and $\mathrm{Cl}$. After a combustion the weight of the residue is determined. Calibration of the apparatus is carried out before and after a series of measurements by combustion of PTU and CBA. The obtained calibration factors and weights obtained were used to calculate the elemental composition of the combusted fraction of the subsamples. Possible interference in the elemental determination may be the decomposition of inorganic material (e.g. carbonates) and formation of non detectable material (e.g. by reaction with material the apparatus consists of, or by formation of inert and non volatile compounds). Most of the interferences are circumvented by humidifying the oxygen stream. Moreover it was found that addition of $\mathrm{V}_{2} \mathrm{O}_{3}$ or $\mathrm{WO}_{3}$ did not result in a significantly different sulfur and carbon contents. $\mathrm{V}_{2} \mathrm{O}_{5}$ and $\mathrm{WO}_{3}$ prevent the formation of metal salt containing $S$ or $C$. So we concluded that no matrix efiects for sulphur and carbon occur in this system.

\section{RESULTS}

Table 1 gives an indication of water type and origin together with the amount of suspended matter and the inorganic fraction. The variation in these two parameters indicates the large difference in water quality at the several sampling sites. Results obtained by analysing samples from various origins are presented in Table 2. The results for chlorine were under its lower limit of detection $(15 \mu \mathrm{g})$. As a consequence they are omitted. The amount of suspended matter was calculated from the weight of solid material after concentrating and drying. The inorganic fraction is defined as the ratio between the weight of the sample after and before combustion.

\section{DISCUSSION}

The results of the elemental analysis of suspended matter are plotted in four graphs. In the graphs presented in Figs 3, 4, 5 and 6, the hydrogen content is plotted vs the carbon content, the nitrogen content

Table 2. Elemental composition of the organic fraction

\begin{tabular}{|c|c|c|c|c|c|c|c|c|}
\hline \multirow[b]{2}{*}{$\begin{array}{l}\text { Sample } \\
\text { number }\end{array}$} & \multicolumn{8}{|c|}{ Elemental content of organic fraction $(\%)$} \\
\hline & $\begin{array}{l}\text { Mean } \\
\text { value }\end{array}$ & SD $^{*}$ & $\begin{array}{l}\text { Mean } \\
\text { value }\end{array}$ & $\mathrm{SD}^{*}$ & $\begin{array}{l}\text { Mean } \\
\text { value }\end{array}$ & SD+ & $\begin{array}{l}\text { Mean } \\
\text { value }\end{array}$ & SD+ \\
\hline 1 & 53.8 & 0.4 & 9.9 & 0.3 & 6.2 & 0.1 & 1.4 & 0.1 \\
\hline 2 & 53.9 & 0.2 & 10.3 & 0.1 & 7.4 & 0.2 & 1.5 & 0.1 \\
\hline 3 & 33.7 & 1.0 & 7.2 & 0.1 & 4.2 & 0.5 & 0.8 & 0.2 \\
\hline 4 & 39.6 & 0.7 & 8.8 & 0.2 & 6.4 & 0.3 & 0.8 & 0.1 \\
\hline 5 & 39.7 & 0.3 & 7.8 & 0.4 & 5.5 & 0.6 & 1.0 & 0.1 \\
\hline 6 & 33.2 & 0.3 & 7.3 & 0.2 & 4.4 & 0.9 & 1.3 & 0.1 \\
\hline 7 & 34.1 & 1.1 & 7.0 & 0.2 & 4.9 & 0.5 & 1.0 & 0.1 \\
\hline 8 & 35.0 & 0.4 & 7.7 & 0.3 & 2.6 & 0.7 & 0.6 & 0.2 \\
\hline 9 & 35.5 & 0.4 & 7.6 & 0.2 & 3.1 & 0.7 & 0.6 & 0.3 \\
\hline 10 & 33.3 & 0.6 & 7.5 & 0.4 & 3.3 & 0.8 & 0.7 & 0.3 \\
\hline 11 & 33.6 & 0.8 & 7.0 & 0.5 & 3.6 & 1.8 & 1.2 & 0.3 \\
\hline 12 & 42.9 & 0.6 & 7.5 & 0.3 & 3.3 & 1.0 & 1.7 & 0.1 \\
\hline
\end{tabular}

- Standard deviation of the mean value calculated from 5 subsamples.

+ Standard deviation of the mean value calculated from 3 subsamples. 


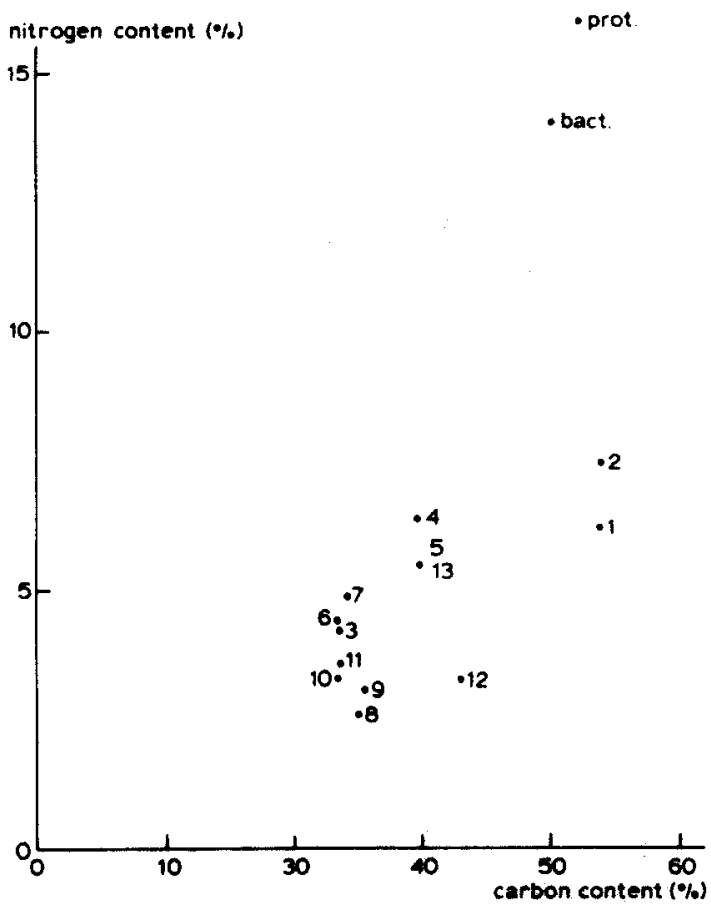

Fig. 3. Plot of hydrogen content vs carbon content determined or calculated for diverse materials. 13: result of the classical method.

vs the carbon content, the sulphur content vs the carbon content and the sulphur content vs the nitrogen content resp. For comparison of our results with those obtainable with classical methods and literature values, the elemental composition of sewage sludge of a waste water treatment plant was determined with

- Classical elemental analysis was carried out by the Institute for Organic Chemistry T.N.O. and supervised by W. J. Buis.

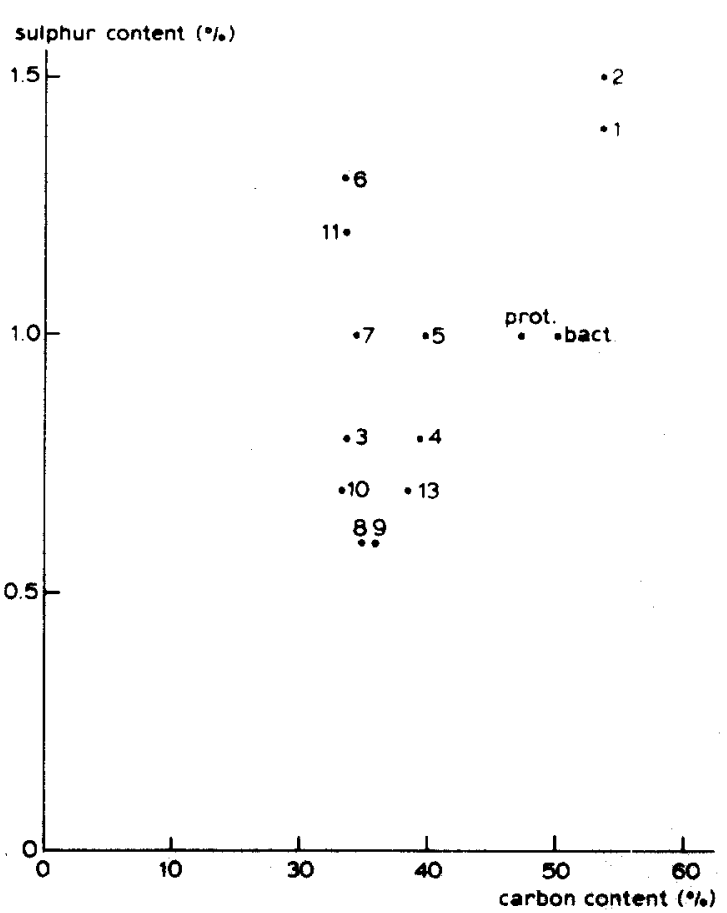

Fig. 5. Plot of sulphur content vs carbon content determined or calculated for diverse materials. 13: result of the classical method.

classical methods*, the mean elemental composition of proteins calculated from the mean elemental composition of proteins given in the literature (Aminosaurengehalten in Futtermitteln, 1976) and the elemental composition of bacteriae (Stanick et al, 1972) and fats (Allinger et al., 1972) was taken from literature too. The results are given in Table 3 and presented where possible in Figs 3-6. As can be seen a

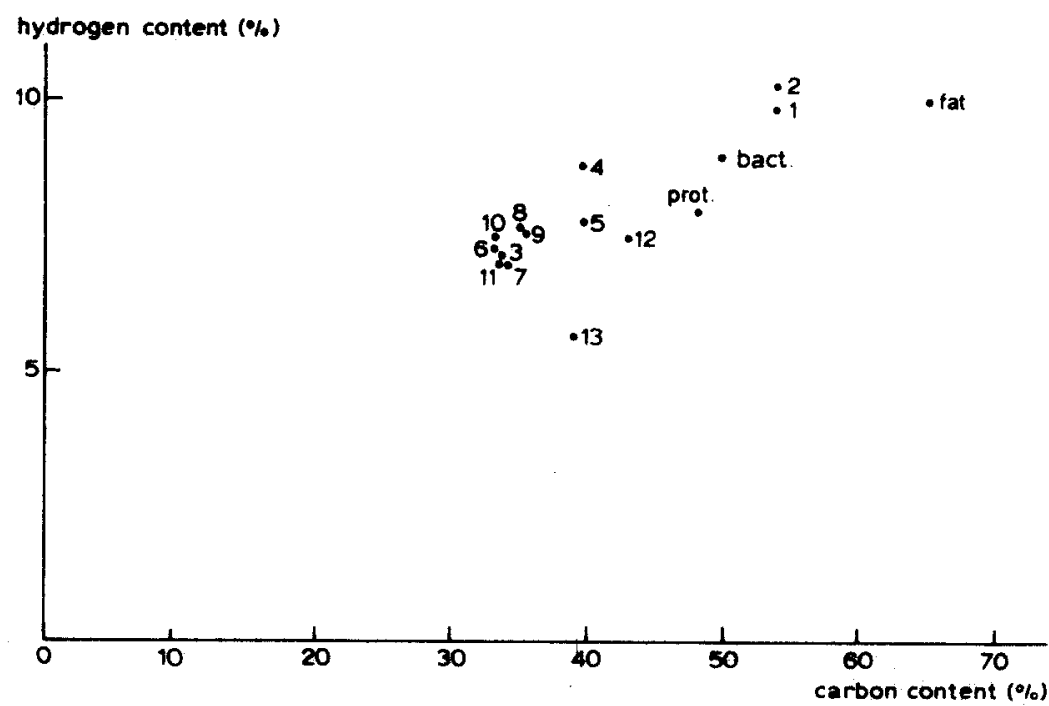

Fig. 4. Plot of nitrogen content vs carbon content determined or calculated for diverse materials. 13: result of the classical method. 


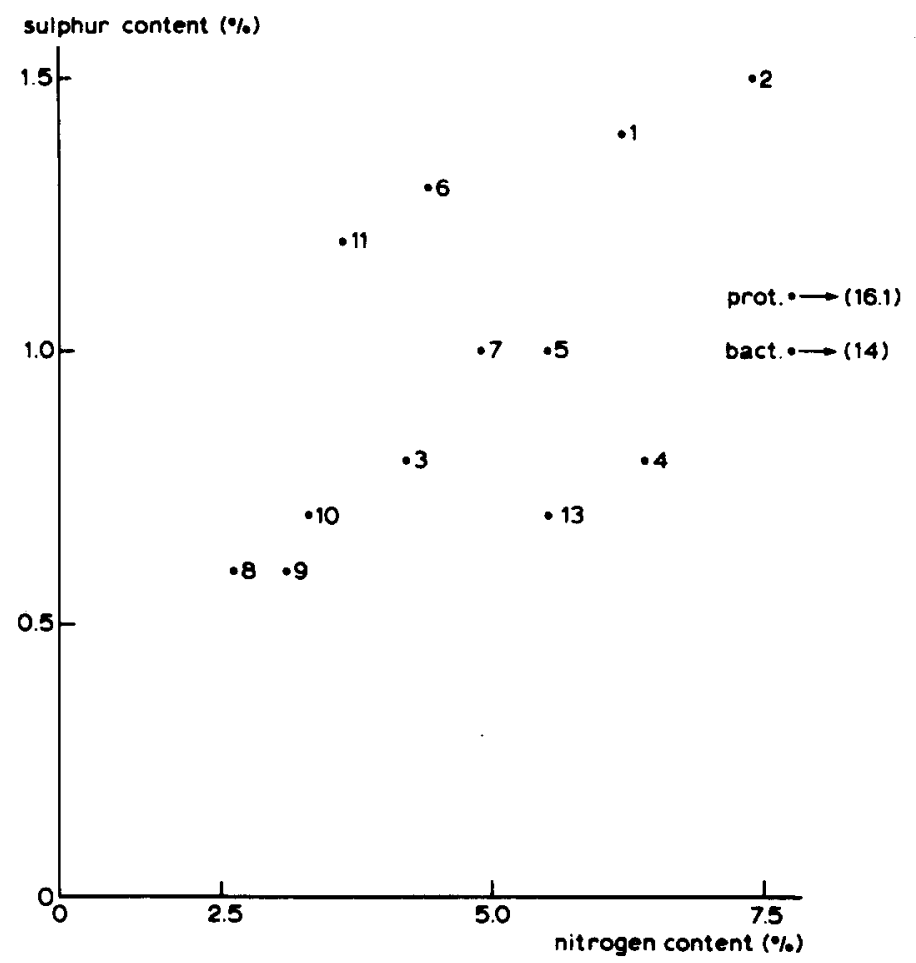

Fig. 6. Plot of sulphur content vs nitrogen content determined or calculated for diverse materials. 13: result of the classical method.

linear relation is only found for the hydrogen content versus the carbon content. It is remarkable that samples with a low inorganic fraction have a high carbon content in the organic fraction. Moreover results from several sampling sites are clustered. However, a relation with the origin of the sample could not be established. On comparing the results of the destruction/QMS-combination with the well-established classical methods of elemental analysis it can be concluded that a certain similarity was obtained. However it could not be ascertained that the organic material originates from organisms.

Recently Baumeister (1978) found for the ratio N/C a value of $0.24 \pm 0.04$ on analysing suspended matter from river water. The standard deviation is remarkably small. This is not in accordance with our results.

Table 3. Mean elemental composition of sewage sludge from waste water treatment plant determined with classical methods; mean elemental composition of protein and fat, and mean elemental composition of bacteriae

\begin{tabular}{ccccc}
\hline & $\begin{array}{c}\text { Classical* } \\
\text { methods } \\
(\%)\end{array}$ & $\begin{array}{c}\text { Protein } \\
(\%)\end{array}$ & $\begin{array}{c}\text { Fat } \\
(\%)\end{array}$ & $\begin{array}{c}\text { Bacteriae } \\
(\%)\end{array}$ \\
\hline $\mathrm{C}$ & $39 \pm 3$ & $48 \pm 3$ & $65 \pm 22$ & $50 \pm 5$ \\
$\mathrm{H}$ & $5.7 \pm 0.5$ & $8.0 \pm 0.5$ & $10 \pm 5$ & $9 \pm 2$ \\
$\mathrm{~N}$ & $5.5 \pm 0.6$ & $16.0 \pm 0.5$ & & $14 \pm 2$ \\
$\mathrm{~S}$ & $0.7 \pm 0.2$ & $1.0 \pm 0.5$ & & $1 \pm 0.3$ \\
\hline
\end{tabular}

* Geometric mean and SD of the mean calculated from 5 determinations.
Probably because he found lower $\mathrm{C}$-values. However from the experiments with and without $\mathrm{V}_{2} \mathrm{O}_{5}$ and $\mathrm{WO}_{3}$ we reject the idea that the higher $\mathrm{C}$-value may be due to carbonates in the sample. The large spread of our results suggests that an attempt to characterize certain kinds of waters based on the elemental composition is useful.

The device used here is able to give more analytical results per hour as the well-established methods do. The loss of accuracy in our method does not seem to be serious enough as the results with respect to several kinds of suspended matter differ to a larger extent.

\section{CONCLUSIONS}

As a conclusion it can be said that a combination of a combustion and QMS-detection of the combustion products can be used for the determination of the elemental composition of organic material in suspended matter in surface water. The time needed for sample preparation and analysis $(30 \mathrm{~min})$ is much smaller than the time needed for classical methods. A further investigation should be carried out in order to determine the variance in the results from different origins more accurately.

Acknowledgement-H. C. E. van Leuven of Koninklijke Shell Laboratory Amsterdam is thankfully acknowledged for his helpful suggestions. U. H. C. Bijvoet of the Organization for Applied Natural Science Research TNO is gratefully thanked for permitting publication of results obtained by W. G. Buis OCI-TNO. Moreover the technical Staff of 
the Laboratory for Physics of the National Institute of Public Health is thanked for their assistance. Furthermore we would like to thank $H$. Trommar of the University of Utrecht for the production of quartz combustion tubes. We thank Dr V. M. Sekhuis for statistical advices.

\section{REFERENCES}

Allinger N. L. et al. (1972) Organic Chemistry, p. 184. Worth, New York.
Aminosäurengehalten in Futtermitteln (1976) Dokumentationsstelle der Universität Hohenheim, DLG-Verlag, Frankfurt.

Baumeister W. (1978) Fres. Z. Analyt. Chem. 289, 86-90.

Leuven H. C. E. van (1970) Anal. Chim. Acta 49, 366

Leuven H. C. E. van (1973) Fres. Z. Anal. Chem. 264, 220.

Stanick R. Y., Doudoroff M. \& Adelberg E. A. (1972) General Microbiology, 3rd edition, p. 67. Prentice-Hall, London. 